"Mircea cel Batran" Naval Academy Scientific Bulletin, Volume XIX - 2016 - Issue 1

Published by "Mircea cel Batran" Naval Academy Press, Constanta, Romania // The journal is indexed in:

PROQUEST / DOAJ / DRJI / JOURNAL INDEX / I2OR / SCIENCE LIBRARY INDEX / Google Scholar / Crossref /

Academic Keys / ROAD Open Access / OAJI / Academic Resources / Scientific Indexing Services / SCIPIO

\title{
HIGH POWER APPLICATIONS OF ELECTROMAGNETIC DEVICES
}

\author{
Vasile DOBREF ${ }^{1}$ \\ Florenţiu DELIU² \\ Paul BURLACU 3 \\ Petrică POPOV 4 \\ Mitrut C. CARAIVAN ${ }^{5}$ \\ ${ }^{1}$ Professor PhD eng. Naval Academy "Mircea cel Batran", Constanța, vasile.dobref@anmb.ro \\ 2Lecturer PhD eng. Naval Academy "Mircea cel Batran", Constanța, florentiu.deliu@anmb.ro \\ 3Lecturer PhD eng. Naval Academy "Mircea cel Batran", Constanța, paul.burlacu@anmb.ro \\ ${ }^{4}$ Lecturer PhD Naval Academy "Mircea cel Batran", Constanța, petrica.popov@anmb.ro \\ ${ }^{5}$ PhD eng., Naval Academy “Mircea cel Batran”, Constanța, caraivanmitrut@gmail.com
}

\begin{abstract}
For the next generation, conventional weapon will touch the best performance limits and will became more and more what in what more an important part plans of improvement systems of weapon to the future. Physical laws that govern electromagnetic propulsion of guns, enabling them higher speeds than those of conventional arms projectiles. This is substantially benefit electromagnetic weapons - using electricity as energy for an electromagnetic weapons.
\end{abstract}

Keywords: electromagnetic weapons; rails, gun

\section{Introduction}

Military programs procurement in recent years, focused on developing two types of weapon missile: on the one hand, directed energy weapon (laser beams or particle) on the other hand, kinetic energy weapons (electromagnetic guns) which retained less attention previously. High energies can be increased by optimizing the performance parameters, but the velocity weapons is close to existing high performance physical and technical limits. For conventional guns, projectile speed limit basic parameters is governed by thermodynamics of gases sprayed. For electromagnetic guns, the limit is governed by the limiting factors of the projectile material characteristics. The speed limit was considered theoretical speed of light. Physical laws that govern electromagnetic propulsion of missiles, enabling them higher speeds than those of conventional arms projectiles.

This is substantially benefit electromagnetic weapons - using electricity as energy for an electromagnetic weapons. Electromagnetic weapons propulsion principle is simple: it is to accelerate a projectile found in a strong electromagnetic field (basically produced by a generator of the same pole) and applied to an electromagnetic accelerator-linear kinetics or coaxial. It can accelerate so as well, particles, aircraft or missiles [2]. In conclusion, the new weapon refers to an electromagnetic gun,that fires projectiles electromagnetic propulsion driven by accelerating electric and electromagnetic field which acts on the projectile.Propulsion system consists of a double conductor, to which the projectile is oriented electrical short-circuited at one end, the other end presenting a place for the accumulation of energy of the electromagnetic field, which is compressed by means of an explosive charge. The invention has the task to make better use of electricity and energy explosive charge carried a cannon electromagnetic acceleration of a projectile which installs compression detonating an electromagnetic field. 
"Mircea cel Batran" Naval Academy Scientific Bulletin, Volume XIX - 2016 - Issue 1

Published by "Mircea cel Batran" Naval Academy Press, Constanta, Romania // The journal is indexed in: PROQUEST / DOAJ / DRJI / JOURNAL INDEX / I2OR / SCIENCE LIBRARY INDEX / Google Scholar / Crossref /

Academic Keys / ROAD Open Access / OAJI / Academic Resources / Scientific Indexing Services / SCIPIO

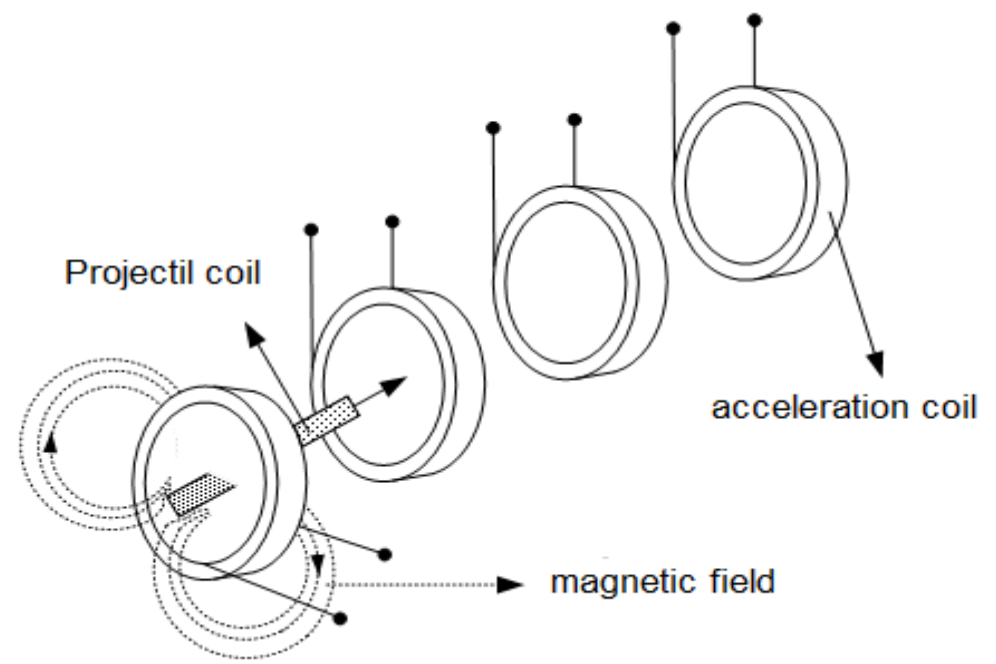

Fig. 1 The operating principle of the electromagnetic coil gun

Device applications in the military are multiple, listing some of them: accelerating masses reduced to achieve high speeds, launching cargo into space, military weapons, nuclear reaction initiation of impact etc.

The oldest form of electromagnetic gun was the gun coil. The gun consists of a pipe coil with a series of accelerator secured. When these coils are connected sequentially to a power supply, there is a magnetic field traveling (travel), which induces a current in the coil and it accelerates the projectile. The operating principle of the electromagnetic coil gun shown in figure 1 is as follows: the magnetic interaction between two currents carrying coils

By tests made by a German research group, it was able to promote a smooth metal disc of $1.3 \mathrm{~g}$ at a speed of $490 \mathrm{~m} / \mathrm{s}$. In the '80s Russian researchers have accelerated a metal disc around the same table at a speed of $4.9 \mathrm{~km} / \mathrm{s}$, the metal disc has undergone an extremely rapid accelerations that is intolerable for military applications. Recently it succeeded as a projectile weighing $1 \mathrm{~kg}$ to be accelerated to a speed of 1.8 $\mathrm{km} / \mathrm{s}$ [1].

To determine the force acting on the projectile we started from the Lorentz force equation.

This characterizes a force acting on the moving charged particles in an electric and magnetic field.

$$
\vec{F}=q \vec{E}+q(v \times \vec{B})
$$

where:

- $\vec{F}$ is the force acting on the task q [N/C];

- $\vec{E}$ is the electric field strength [N/ m];
- $\vec{B}$ is the magnetic flux density $[\mathrm{T}]$;

- $\quad \mathrm{v}$ is the velocity of the particle $[\mathrm{m} / \mathrm{s}]$;

- $q$ particle charge $q[C]$.

In this example, we really mean by $q$ an electric current with in projectile, disposed between the rails. To estimate the force needed to accelerate, must analyzing the second term of equation (1). Knowing:

$$
\begin{aligned}
& \text { we get: } \quad q[\mathrm{C}] \cdot v[\mathrm{~m} / \mathrm{s}]=i \\
& \vec{F}=q(v \times \vec{B})=i(d l \times \vec{B})
\end{aligned}
$$

At a given value of the current intensity, the force acting on the projectile will be proportional to its length, and the value of the magnetic field will be given of the configuration of the rails. Expression of the force exercised on the projectile, expressed in terms of the current $i$, the distance $d$ between the conductive rails and the track radius $r$, is given by the equation (4):

$$
\begin{gathered}
F=\frac{\int_{0}^{d} \mu \times i^{2}}{4 \pi\left(\frac{1}{(r+d-\rho)}+\frac{1}{(r+\rho)}\right) d \rho} \\
F=\frac{\mu-i^{2}}{2 \pi} \ln \left(\frac{r+d)}{r}\right)
\end{gathered}
$$

where:

- $\mu$ magnetic permeability is;

- $i$ is the intensity of electric current;

- $d$ is the distance between the rails;

$-r$ is the radius of conductive rails;

$-\rho$ is the distance at which the force is measured

The equation is applicable with certain limitations due to approximations, but it allows calculation of current necessary to produce a force $F$ data. Using materials with high strength magnetic 
"Mircea cel Batran" Naval Academy Scientific Bulletin, Volume XIX - 2016 - Issue 1

Published by "Mircea cel Batran" Naval Academy Press, Constanta, Romania // The journal is indexed in: PROQUEST / DOAJ / DRJI / JOURNAL INDEX / I2OR / SCIENCE LIBRARY INDEX / Google Scholar / Crossref /

Academic Keys / ROAD Open Access / OAJI / Academic Resources / Scientific Indexing Services / SCIPIO

permeability $\mu$, it can be increased if it optimized relation between $r$ and $d$.

$B$ is the magnetic induction:

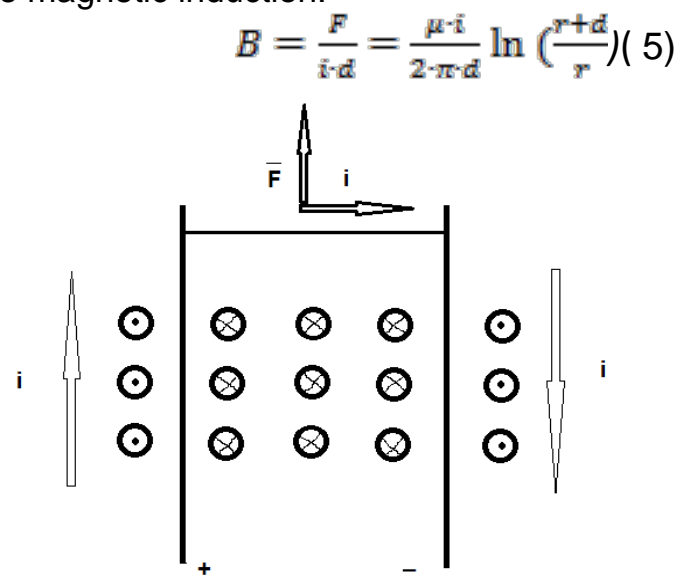

Fig.2 Principle of application necessary acceleration of the projectile. High performances requires a large amount of electricity, about tens of giga watts, which can be supplied on board of military vessels equipped with electrical power plant with turbo-generators, having high voltage type systems $(6 \mathrm{kV} / 50 \mathrm{~Hz}$ or $6.6 \mathrm{kV} / 60 \mathrm{~Hz})$.

\section{Experimental set-up}

Cannon rail gun is an advanced form of electromagnetic gun. In principle, it consists of two parallel rails projectile, by sliding between them. When a power source is connected to rails, current flows through a rail projectile through a wire armature, at the base of the projectile in the other track and back in the other direction through the other rail. The operating principle of electromagnetic rail gun, shown in Figure 3 , is as follows: current creates a magnetic field, the Lorentz force acting on a current flowing through the valves and so the projectile is accelerated.

Thus, equations 4 and 5 allow us to calculate the estimated current and magnetic induction $B$, as a
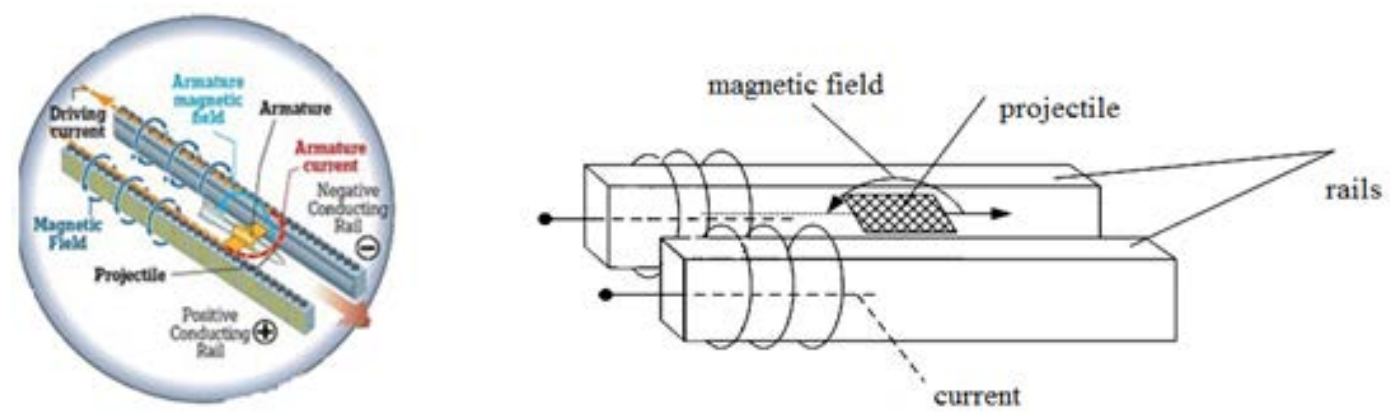

Fig. 3 The operating principle of electromagnetic rail gun

In experiments it managed to accelerate plasmas with very low mass at speeds exceeding $100 \mathrm{~m} / \mathrm{s}$ and projectiles, weighing tens of grams at speeds of $4.8 \mathrm{~m} / \mathrm{s}$ [3]. The power source for electromagnetic guns tests performed with different types of electromagnetic guns have shown that they can achieve higher muzzle velocities than conventional guns. But tests have not been able to demonstrate energy necessary applications because energy sources were missing. Thus, a priority in this project is the development of energy storage device. The power that must provide an energy storage device is of the order of one million kilowatts, and the necessary currents are of the order of one million amps. A solution can be the energy storage under one of four methods: electrostatic, electromagnetic, electrochemical and mechanical. Technical forms of these four processes are: condenser (capacitor), pulse transformer, battery storage and pulse generator. Capacitors existing technical reasons, can not be used, pulse transformer is very good, but only in volume terms. The impulse must ensure amps current for 1.6 million. Modern auto-pulse generator is too high for them to ensure such impulses. Even though the accumulated energy is several times the necessary electrical system can deliver only a part of the output. The pulse generator as a homopolar installations is the best environment for accumulation of power in the conditions necessary volume. A new type of generator, "compulsive" is a derivation of conventional alternating current generator. His special feature 
"Mircea cel Batran" Naval Academy Scientific Bulletin, Volume XIX - 2016 - Issue 1

Published by "Mircea cel Batran" Naval Academy Press, Constanta, Romania // The journal is indexed in:

PROQUEST / DOAJ / DRJI / JOURNAL INDEX / I2OR / SCIENCE LIBRARY INDEX / Google Scholar / Crossref /

Academic Keys / ROAD Open Access / OAJI / Academic Resources / Scientific Indexing Services / SCIPIO

is an additional stationary coil connected in series to the voice coil. Additional changes periodically auto-induction coil arrangement. If stationary coil is located in the magnetic field $B$, the inductance $L$ reaches its minimum exactly at the point where the induced voltage $u$ is maximum. The result is a very powerful discharge current when the circuit is open to consumer power. The capacity to deliver very strong current periodic downloads, according to the frequency of rotation (ex. $50 \mathrm{~Hz}$ ) makes it useful as an energy source for electromagnetic guns which should have a high-speed shooting. In addition, the duration of the order of over currents 0.3 to $2 \mathrm{~ms}$, which is the time required for a projectile to pass through pipes of small arms and environment. As a result is possible to eliminate the need for a coil and a switch for forming pulses [4].

\section{CONCLUSION}

Progress on the accelerator, energy accumulation and formation impulses make future weapons systems to be equipped with an electromagnetic gun. To achieve this will require intense research work for all matters involving electromagnetic cannon, including power supply and projectiles. Electromagnetic cannon, besides military importance, proves to be a means of progress and technological innovation, with a considerable impact on the civilian.

\section{BIBLIOGRAPHY}

[1] Pierrre Langereux - „Air et cosmos”, Nr. 1046, 1995, pag. 37

[2] Oae Alexandru - „Posibilităţi de utilizare a motoarelor liniare de inducţie pentru mijloacele de luptă navale” -, Universitatea Tehnică „Gh Asachi” 2003, pag. 50 - 62

[3] Horvath Kalman - „Elektromagness lovegek”, Haditechnika, 1988, pag. 13 - 17

[4] Wolfram Witt, Markus Loffler - „Elektromagnetische Kanone”, Technik 1995, pag. 34-35 